\title{
The Effect of Neutron Irradiation on Second \\ Phase Precipitation Processes*
}

\author{
By Z. E. OSTROVSKY, ${ }^{* *}$ G. A. SERNYAEV, ${ }^{* *}$ P. P. GRINTCHUK, ${ }^{* *}$
}

S. N. VOTINOV,** and V.I. PROKHOROV ${ }^{* *}$

\section{Synopsis}

The effect of neutron irradiation on OX16H15M35 austenitic stainless steel ageing was investigated in this work by electron microscopy. It was shown that after irradiation up to $1.9 \times 10^{20} \mathrm{n} / \mathrm{cm}^{2}(E \geq 1 \mathrm{Mev})$ at $680^{\circ}$ to $700^{\circ} \mathrm{C}$ the acceleration of the excessive phase precipitation processes took place. The results of this work as well as the data previously obtained for irradiation effects on some stainless steels ageing are interpreted with the scheme of the excessive phase temperature range displacement to lower temperatures under irradiation.

The displacement scheme suggested is confirmed by the results of structure investigations on a series of other ageing alloys (e.g. on $\mathrm{Al}-\mathrm{Si}-\mathrm{Mg}$ alloy after irradiation at $50^{\circ}$ to $60^{\circ} \mathrm{C}$ and $110^{\circ}$ to $130^{\circ} \mathrm{C}$ ).

\section{Introduction}

It is known that physical and mechanical properties of the constructive materials are closely related to their structure. In this connection the problem of neutron irradiation effects on structural changes is of great interest.

The purpose of this paper is to ascertain the regularities of structural changes in some dispersedly-hardening materials under the high-temperature neutron irradiation.

\section{Materials}

\section{OX16H15M35 Steel}

The structure of OX16H15M35 stainless steel was investigated in this work, and its chemical composition and thermal treatment after neutron irradiation and after ordinary thermal ageing is given in Table 1.

The cylindrical specimens with $6.5 \mathrm{~mm}$ in diameter and $6 \mathrm{~mm}$ in length were irradiated in CM-2 reactor in helium at the temperature of $680^{\circ}$ to $700^{\circ} \mathrm{C}$ by the integral fluxes of fast $(\mathrm{E} \geq 1 \mathrm{Mev})$ and thermal neutrons up to $2 \cdot 10^{20}$ and $1.5 \cdot 10^{20} \mathrm{n} / \mathrm{cm}^{2}$, respectively. The effective irradiation time was $400 \mathrm{hr}$.

\section{2. $\mathrm{Al}-\mathrm{Mg}-\mathrm{Si}$ Alloy}

The chemical composition of aluminium alloy investigated is given in Table 2 .

In order to obtain the different structural states a portion of the specimens with the initial thermal treatment was subjected to the artificial ageing at $230^{\circ} \mathrm{C}$ during 3, 5, 14, and $20 \mathrm{hr}$. Irradiation of both initial and differently aged alloy specimens was carried out in CM-2 reactor at temperatures of $50^{\circ}$ to $60^{\circ} \mathrm{C}$ and $100^{\circ}$ to $130^{\circ} \mathrm{C}$ by fast neutron flux of $5.4 \cdot 10^{20} \mathrm{~cm}^{2}$ $(\mathrm{E} \geq 1 \mathrm{Mev})$.

\section{Experimental Procedure}

Structural investigations of steel were carried out by the carbon-varnish replica method on уэмв-100 electron microscope. The specimens were investigated in initial state after ageing at temperature of $700^{\circ} \mathrm{C}$ during $400 \mathrm{hr}$ and after neutron irradiation.

Electropolishing and etching of specimens were carried out in acetochromic electrolyte $(133 \mathrm{~mm}$ of icy acetic acid, $25 \mathrm{ml}$ of water, $25 \mathrm{~g}$ of chromic anhydride) at voltage of 30 to $35 \mathrm{~V}$.

Structural changes in Al-alloy were investigated by carbon-varnish and oxide replica on electron microscope уэмв- 100 .

Besides, all the specimens were measured on microhardness.

\section{Experimental Results}

1. Stainless Steel

Table 1. Chemical composition and treatment of OX16H15M35 steel

\begin{tabular}{|c|c|c|c|c|c|c|c|c|c|c|}
\hline \multicolumn{10}{|c|}{ Chemical composition (wt \%) } & \multirow{2}{*}{ Initial thermal treatment } \\
\hline C & $\mathrm{Si}$ & $\mathrm{Mn}$ & $\mathrm{S}$ & $P$ & $\mathrm{Cr}$ & $\mathrm{Ni}$ & Mo & $\mathrm{Nl}$ & $\mathrm{Fe}$ & \\
\hline 0.06 & 0.44 & 0.58 & 0.007 & 0.013 & 16.88 & 14.75 & 2.84 & 0.47 & Base & $\begin{array}{l}\text { Austenitization at } 1120^{\circ} \mathrm{C} \text { for } 0.5 \mathrm{hr} \\
\text { air cooling }\end{array}$ \\
\hline
\end{tabular}

Table 2. The chemical composition and initial thermal treatment of $\mathrm{Al}-\mathrm{Mg}-\mathrm{Si}$ alloy

\begin{tabular}{ccccccc|c}
\hline \multicolumn{9}{c}{ Chemical composition $(\mathrm{wt} \%)$} & & Initial thermal treatment \\
\hline $\mathrm{Si}$ & $\mathrm{Mg}$ & $\mathrm{Fe}$ & $\mathrm{Zn}$ & $\mathrm{Cu}$ & $\mathrm{Ti}$ & $\mathrm{Al}$ & \\
\hline 0.81 & 0.48 & 0.085 & 0.011 & 0.0058 & 0.004 & Base & $\begin{array}{l}\text { Homogenizing annealing at } 530^{\circ} \mathrm{C}, \text { harden- } \\
\text { ing into water, natural ageing during 2hr }\end{array}$ \\
\hline
\end{tabular}

* Received November 21, 1970.

** Scientific Research Institute of Atomic Reactors, Melekess-10, Ulyanovsk, USSR. 
Photographs 1 (a) to (c) show the microstructures of OX16H15M35 stainless steel after the initial thermal treatment, ageing, and irradiation.

By means of X-ray crystal and chemical analyses it was shown ${ }^{1,2)}$ earlier that depending on ageing conditions of this steel there may have been precipitated mainly three strengthening phases; $\mathrm{MoFe}_{2}, \mathrm{Nb}(\mathrm{C}$, $\mathrm{N})$, and $\mathrm{Me}_{23} \mathrm{C}_{6}$.

As it is seen from Photo. 1 (a) OX16H15M35 steel has usual austenitic structure with some primary carbides content in initial state.

After ageing at $700^{\circ} \mathrm{C}$ during $400 \mathrm{hr}$ the closely spaced precipitations of $\mathrm{MoFe}_{2}$ intermetallides (as well as $\mathrm{Me}_{23} \mathrm{C}_{6}$ carbides chains) are observed on the grain boundaries and have the characteristic elongated form ${ }^{3}$ )

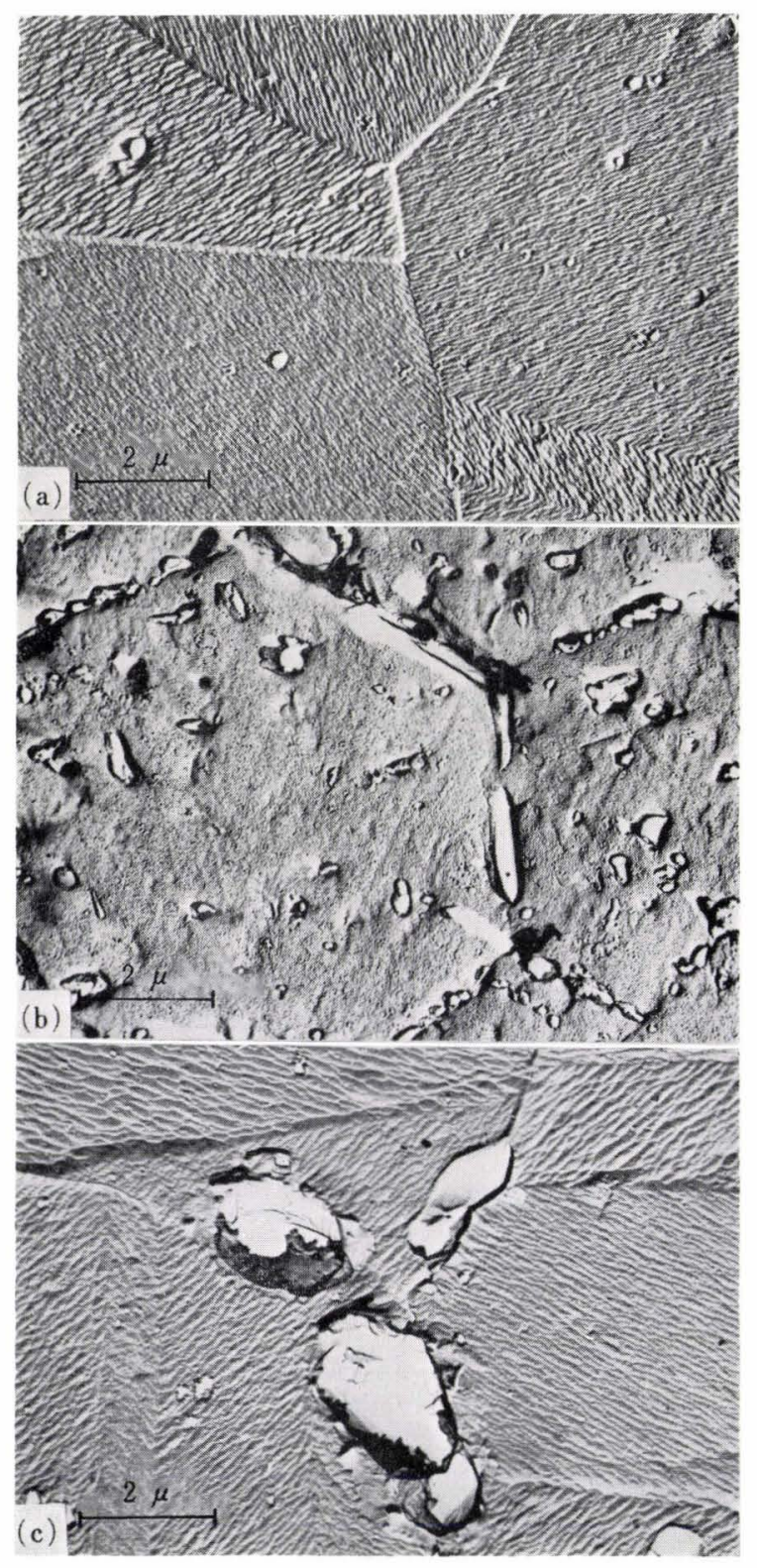

Photo. 1. The microstructures of OX16H15M35 steel
(a) Initial
(b) After ageing at $700^{\circ} \mathrm{C}$ during $400 \mathrm{hr}$
(c) After irradiation at $680^{\circ}$ to $700^{\circ} \mathrm{C}$
$\left(2 \cdot 10^{20} \mathrm{fn} / \mathrm{cm}^{2}\right)$

at the length of $2 \mu$ and width of about $0.3 \mu$ (Photo. 1 (b)).

Analogous inclusions are present within the grains as well. But after neutron irradiation at $680^{\circ}$ to $700^{\circ} \mathrm{C}$, as it is seen from Photo. 1 (c), only greatly increased and coagulated precipitations of $\mathrm{MoFe}_{2}$ iron molibdenides are at the boundaries and partially within the grains, $\mathrm{Me}_{23} \mathrm{C}_{6}$ carbides precipitations being almost absent.

From the comparison of aged and irradiated specimens microstructures it is obvious that irradiation promotes the achievement of more profound ageing stages.

\section{Al-Alloy}

The $H \mu$ microhardness dependence on initial specimens ageing time at $230^{\circ} \mathrm{C}$ for unirradiated alloy (curve 1) and for irradiated ones at $50^{\circ}$ to $60^{\circ} \mathrm{C}$ (curve 2) and at $110^{\circ}$ to $130^{\circ} \mathrm{C}$ (curve 3 ) is shown in Fig. 1.

As it is seen from Fig. 1 (curve 1) $\mathrm{H} \mu$ microhardness dependence of unirradiated specimens is characterized by two hardening maxima the first of which occurs after ageing during an hour and the second one during $27 \mathrm{hr}$. After irradiation at $50^{\circ}$ to $60^{\circ} \mathrm{C}$ we observed the shift of both hardening maxima to smaller agening times (Fig. 1, curve 2).

Therefore, the first maximum is achieved by irradiation of specimens with initial thermal treatment, and the second by that of specimens aged at $230^{\circ} \mathrm{C}$ during $20 \mathrm{hr}$. This effect is revealed more pronounced after irradiation at $110^{\circ}$ to $130^{\circ} \mathrm{C}$ (Fig. 1, curve 3). It should be noted that without irradiation the annealing of initial specimens at the temperature of $110^{\circ} \mathrm{C}$ does not lead to essential changes of microhardness even during $5000 \mathrm{hr}$.

Microstructural investigations also show that as a result of irradiation the acceleration of hardening phase

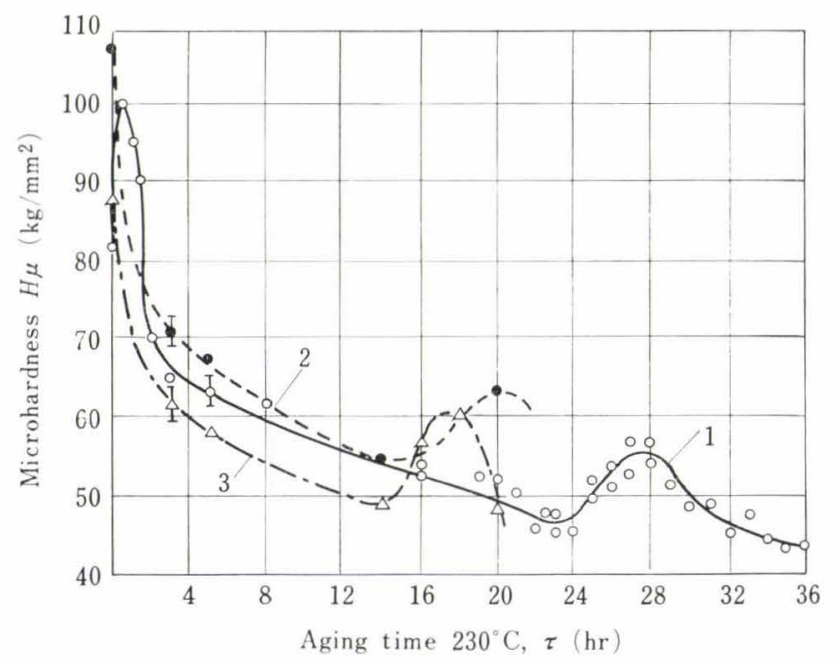

Fig. 1. $H_{\mu}$ microhardness dependence of $\mathrm{Al}-\mathrm{Si}-\mathrm{Mg}$ alloy upon ageing duration at $230^{\circ} \mathrm{C}$

1: without irradiation

2: after irradiation at $50^{\circ}$ to $60^{\circ} \mathrm{C}, 5.4 \cdot 10^{20} \mathrm{fn} / \mathrm{cm}^{2}$

3: after irradiation at $110^{\circ}$ to $130^{\circ} \mathrm{C}, 5.4 \cdot 10^{20} \mathrm{fn} / \mathrm{cm}^{2}$ 


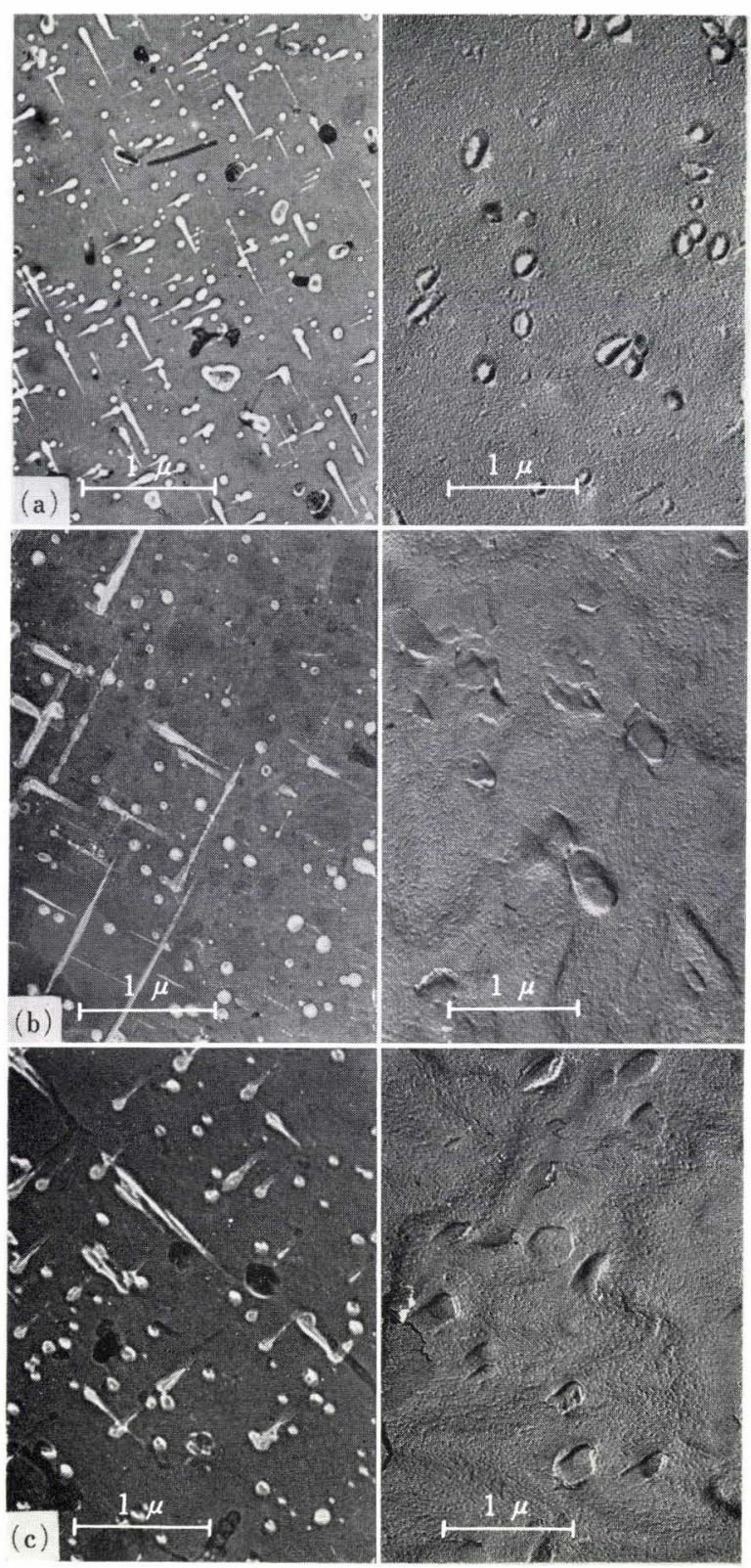

Photo. 2. Al-Si-Mg alloy structures

(a) after ageing at $230^{\circ} \mathrm{C}$ during $14 \mathrm{hr}$,

(b) after ageing at $230^{\circ} \mathrm{C}$ during $24 \mathrm{hr}$,

(c) after ageing at $230^{\circ} \mathrm{C}$ during $14 \mathrm{hr}$,

and subsequent neutron irradiation $\left(5.4 \cdot 10^{20} \mathrm{fn} / \mathrm{cm}^{2}\right)$

at temperatures of $110^{\circ}$ to $130^{\circ} \mathrm{C}$

(Left: oxide replica, right: carbon replica)

precipitation processes occurs in $\mathrm{Al}-\mathrm{Si}-\mathrm{Mg}$ alloy.

For example, irradiation at $110^{\circ}$ to $130^{\circ} \mathrm{C}$ of the alloy aged at $230^{\circ} \mathrm{C}$ during $14 \mathrm{hr}$ leads to the structural specimen state undergone the preirradiated annealing at $230^{\circ} \mathrm{C}$ during $24 \mathrm{hr}$. The corresponding microstructures are given in Photos. 2 (a) to (c).

\section{Discussion}

Taking into account these experimental results as well as those on microstructural investigations of neutron irradiated OOX16H15, OX16H15M3БР, X15 H35B3T, X15H35М2ТЮБ austenitic stainless steels

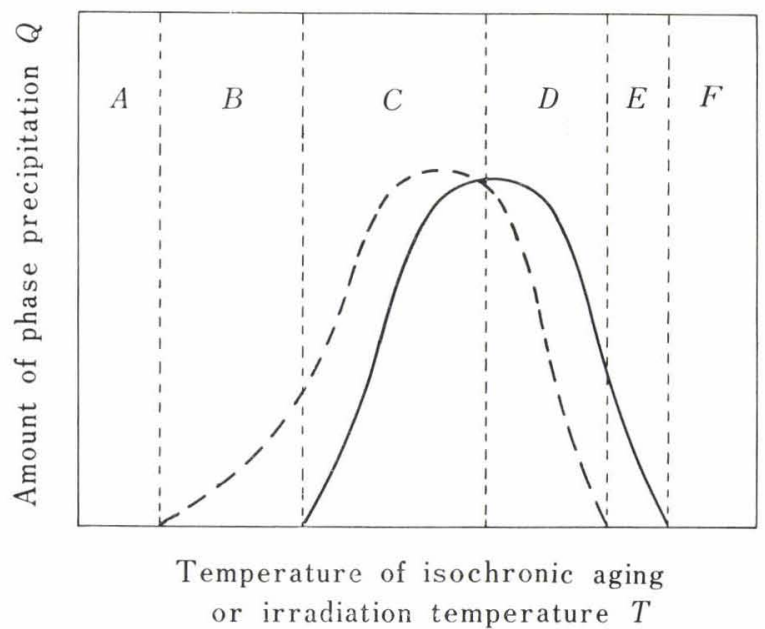

Fig. 2. The dependence of the amount of phase precipitation $Q$ upon temperature $T$ of isochronic ageing (solid line) or on irradiation (dotted line)

obtained previously, ${ }^{4)-6}$ ) one may point out the following peculiarities of radiation effects on an excessive phase precipitation;

(1) The enlargement and coagulation of some phase precipitations (e.g. $\mathrm{MoFe}_{2}$ intermetallides in OX16H15M3Б and X15H35M2TЮБ steels, $\mathrm{Mo}_{23} \mathrm{C}_{6}$ carbides, $\gamma^{\prime}$-phase $\left(\mathrm{Ni}_{3} \mathrm{Ti}\right)$ in $\mathrm{X} 15 \mathrm{H} 35 \mathrm{~B} 3 \mathrm{~T}$ steel and phase $\mathrm{Mg}_{2} \mathrm{Si}$ in $\mathrm{Al}-\mathrm{Mg}-\mathrm{Si}$ alloy).

(2) New phases appearance being absent in unirradiated specimens ( $\gamma^{\prime}$-phase in X15H35М2ТЮБ steel).

(3) Sharp decrease or complete disappearance of some phases $\left(\mathrm{Me}_{23} \mathrm{C}_{6}\right.$ carbides in OX16H15M35, OX16H15M3БP steels, $\chi$-phase (Cr-Ni-Mo-Ti) in X15H35М2ТЮБ steel.

These peculiarities may be qualitatively interpreted by the temperature ranges of the excessive phase existence in this matrix. The lower boundary of such a range will be determined by the excessive phase precipitation onset which can be observed by means of the investigation methods used and the upper one by its solution limit. Speeding up the diffusion processes the irradiation displaces the temperature range of the second phase existence to lower temperatures. This displacement is schematically given in Fig. 2 and shows the dependence of $Q$-phase relative quantity precipitated from solid solution upon isochronic ageing temperature $\mathcal{T}$ (solid line) or on irradiation (dotted line). Being one of the most effective way for bringing alloys into higher equilibrium, ${ }^{7}$ the irradiation leads not only to $Q(T)$ curves displacement but also to some increase of the precipitated phase maximum.

There are some temperature ranges $(A, B, C, D, E$, $F$ ) on the scheme within which the annealing or irradiation will lead to the formation of structures with the different quantity of the second phase in unirradiated and irradiated specimens.

This scheme is also suitable for the analysis of radiation effects on multicomponent alloys in which every phase is characterized by its temperature range exist- 
ence.

For example, in OX16H15M35 stainless steel the relative quantity of $\mathrm{MoFe}_{2}$ intermetallide in the electrolytic deposits is increased from ageing temperature of about $550^{\circ} \mathrm{C}$ and reaches its maximum at about $750^{\circ} \mathrm{C}$, being decreased at higher temperatures. At the same time the decreasing of $\mathrm{Me}_{23} \mathrm{C}_{6}$ carbide relative quantity in these deposits occurs at the ageing temperature higher than $600^{\circ} \mathrm{C} .{ }^{1), 2}$ ) Therefore, after ageing at $700^{\circ} \mathrm{C}$ both $\mathrm{Me}_{23} \mathrm{C}_{6}$ carbides associated with their precipitation process relaxation and $\mathrm{MoFe}_{2}$ intermetallides which are characterized by this phase precipitation increasing will be present in unirradiated specimens. This can be observed on microstructure given by Photo. 1 (b). After irradiation at $680^{\circ}$ to $700^{\circ} \mathrm{C}$, as it is seen in Photo. 1 (c), large precipitations of $\mathrm{MoFe}_{2}$ were observed in OX16H15M36 steel at their coagulation stage and those of $\mathrm{Me}_{23} \mathrm{C}_{6}$ carbides in $D$ region characterized by this phase precipitation relaxation under irradiation.

The results for irradiation effects on structural conversions in ageing binary alloys are also kept within the scheme suggested. R. H. Kernohan et al. ${ }^{8)}$ pointed out that in $\mathrm{Ni}-2 \% \mathrm{Be}$ alloy irradiated by neutrons at room temperature and at $300^{\circ} \mathrm{C}$ the excessive precipitation $(1.3 \%)$ of beryllium atoms was observed only in the latter case. The same effect takes place at $300^{\circ} \mathrm{C}$ and in unirradiated specimens as well but to an inconsiderable degree. Thus, the precipitations of beryllium atoms from solid solution under irradiation at room temperature are characterized by $A$ region in a scheme suggested, and under irradiation at $300^{\circ} \mathrm{C}$ by $B$ region. On the other side in $\mathrm{Cu}-2.2 \mathrm{wt} \%$ Be alloy in which the excessive beryllium atoms precipitation begins at lower temperatures compared with $\mathrm{Ni}-2 \% \mathrm{Be}$ alloy the neutron irradiation up to $3.10^{19} \mathrm{n} / \mathrm{cm}^{2}$ at $40^{\circ} \mathrm{C}$ leads to the same structural state as in the case of ordinary thermal heating structural state as in the case of ordinary thermal heating at $150^{\circ} \mathrm{C}$ during the time equal to that of irradiation, ${ }^{9), 10)}$ i.e. ageing is characterized here by $B$ region.

Every point of $Q(T)$ dependence is corresponded to on the definite physical and chemical properties of the materials obtained under given ageing conditions. It is known that these properties are determined by the alloy structure peculiarities and depend on many factors (upon the type and quantity ration of the excessive phases, their dispersity extent, distribution, precipitation density, interaction with matrix lattice and different defects etc.). Therefore, the irradiation resulting in the structure changes will also affect the physical and mechanical properties of alloys. Therefore, their definite level may be attained at the different ageing conditions rather than under irradiation. Thus, $Q(T)$ curves displacement will be associated with that of some other dependences such as for example electrical resistivity and microhardness.

So, H. Herman ${ }^{11}$ investigated the electrical resistivity of $\mathrm{Al}-5.3$ at $\% \mathrm{Zn}$ depending on isochronic annealing at the temperatures of $-195^{\circ}$ up to $175^{\circ} \mathrm{C}$ in unirradiated and proton irradiated $(\mathrm{E}=20.5 \mathrm{Mev})$

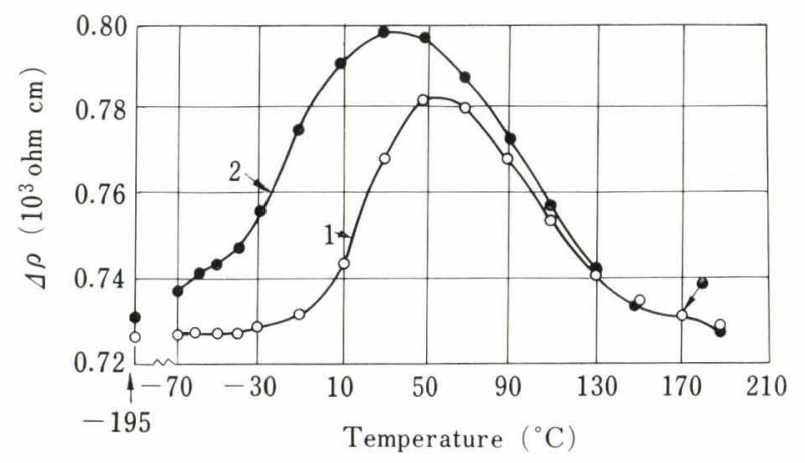

Fig. 3. Al-5.3 at $\% \mathrm{Zn}$ alloy electrical resistivity changes against the isochronic annealing temperature ${ }^{11}$

specimens and found that $\Delta \rho(T)$ dependence for irradiated specimens displaces to lower temperatures. The displacement character is analogous to Q(T) dependence displacement suggested (Fig. 3).

Thus, considering the peculiarities of radiation effects on the excessive phase precipitation processes both in austenitic stainless steels and in other aged alloys one can observe the fact that under irradiation at temperatures providing the vacancies mobilities there may be achieved the later ageing stages compared with unirradiated control specimens. These stages can be achieved without irradiation by ageing at higher temperatures and exposing times or not be achieved at all.

The phenomenon considered which may be described as radiation ageing makes an essential contribution to changes of high temperature mechanical properties of alloys under irradiation, in particular, to high temperature radiation embrittlement of steels and alloys susceptible to the embrittlement without irradiation.

\section{Conclusion}

(1) It has been found that the neutron irradiation of OX16H15M35 austenitic stainless steel with $1.9 \times$ $10^{20} \mathrm{n} / \mathrm{cm}^{2}(\mathrm{E} \geq 1 \mathrm{Mev})$ at the temperature of $680^{\circ}$ to $700^{\circ} \mathrm{C}$ leads to; (a) the embrittlement and coagulation of $\mathrm{MoFe}_{2}$ intermetallide particles, (b) the sharp reduction of $\mathrm{Me}_{23} \mathrm{C}_{6}$ type carbides.

(2) It has been shown that the neutron irradiation with $5.4 \times 10^{20} \mathrm{n} / \mathrm{cm}^{2}(\mathrm{E} \geq 1 \mathrm{Mev})$ at $50^{\circ}$ to $60^{\circ} \mathrm{C}$ and $110^{\circ}$ to $130^{\circ} \mathrm{C}$ accelerates the precipitation of $\mathrm{Mg}_{2} \mathrm{Si}$ in $\mathrm{Al}-\mathrm{Mg}-\mathrm{Si}$ alloy as well.

(3) The scheme is presented, which gives the explanation to the high temperature neutron irradiation effects on dispersedly-hardening alloy behaviour.

\section{REFERENCES}

1) Н.П. Агапова, Ф.П. Бутра и С.Н. Вотинов: ФМиМ, том ІХ, вып. 3 (1960), 422.

2) Е. Ф. Яковлева и др.В сб. : трудов ЦНИИчМ “Новые методы испытаний металлов" Изд. “Металлургня", М., вып. 49, (1966), р. 10"'-109.

3) А. В. Смирнова: “Зав. лаб.”, (1963), №. 8, 948.

4) S. N. Votinov et al.: Trans. JIM, 9 (1968), Supplement, 238.

5) В. Д. Балашов и др. В сб.: "Radiation Damage in Reactor Materials ", Vol. 1, (1969), 429, Vienna. 
6) С. Н. Вотинов и др.: “Атомная энергия”, т. 27 вып 6 (декабрь 1969), р. 506.

7) С. Т. Конобеевский : “Действие облучения на материалы” Атомиздат, М, 1967.
8) R. H. Kernohan et al.: J. Appl. Phys., 27 (1956), 40.

9) D. S. Billington and S. Siegel: Metal Prog., 58 (1950), 847.

10) G. T. Murrey and W. E. Taylor: Acta Met., 2 (1954), 52.

11) H. Herman: Acta Met., 2 (1964), 52. 